\title{
Microcephaly in Zika Virus Infection
}

\author{
Erica L Mc Grath ${ }^{1}$ and Ping Wu ${ }^{2}$ \\ ${ }^{1}$ Department of Neuroscience and Cell Biology, University of Texas, USA \\ ${ }^{2}$ Beiging Institute for Brain Disorders, Capital Medical University, China
}

Submission: May 31, 2017; Published: June 14, 2017

*Corresponding author: Ping Wu, Beiging Institute for Brain Disorders, Research Building 17, Room 4.212 B, 301 University Blvd. Galveston, TX 77555, USA, Tel: (409) 772-9858; Fax: (409) 747-2187; Email: piwu@utmb.edu

Abstract

Zika virus is a flavivirus known to cause microcephaly during development. The mechanism underlying Zika virus-induced neuropathogenesis is still poorly understood. Recent studies have utilized the cutting edge cell culture and animal model technologies to elucidate factors contributing to Zika virus-associated microcephaly. While future work is needed, current studies have suggested three main factors that contribute to Zika virus pathology: viral lineage, host immunity, and pregnancy stages. This mini review will focus on some of the recent findings that advanced our knowledge in Zika virus-associated microcephaly.

Keywords: Zika virus; neural stem cells; microcephaly

Abbreviations: ZIKV: Zika Virus; NSC: Neural Stem Cells; CT: Computed Tomography; TPCR: Transcription-Polymerase Chain Reaction

\section{Introduction}

Zika virus (ZIKV) is a flavivirus transmitted by the Aedes aegypti and Aedes albopictus mosquitoes with recent outbreaks in the Americas, and 84 countries and territories reporting active ZIKV transmission [1-3]. One of the greatest concerns regarding ZIKV infection is the risk of microcephaly. Microcephaly is a neurodevelopmental disorder characterized by a head size less than 2 standard deviations below the mean typical head size [4]. Infants with microcephaly can have a range of problems such as developmental delays, seizures, vision and hearing loss, and difficulty feeding.

There are two primary lineages of ZIKV, African and Asian; however, to date, only strains of the Asian lineage are associated with microcephaly [1,5-9]. The causal link between microcephaly and ZIKV infection was confirmed in 2016, as well as the capability of ZIKV to be transmitted by mosquito bites, sexual contact and contact with other bodily fluids [10-13]. ZIKV has been detected in placental, amniotic fluid, and brain cells [10,13-15]. Additionally, there has been a significant increase in microcephaly in Brazil linked to the ZIKV outbreak.

The WHO declared ZIKV-associated microcephaly and other ZIKV-related neurological disorders to be a "public health emergency of international concern". An estimated 0.034\% to $13.2 \%$ of infants born to pregnant infected mothers will develop microcephaly $[4,13,15-18]$. It remains unclear what factors determine the susceptibility to ZIKV-related neurological abnormalities, though it is hypothesized that different ZIKV strains, pregnancy stages, and individual differences impact the response to ZIKV infection [16,17,19-21].

\section{In vitro studies regarding ZIKV contributions to microcephaly}

A normal brain develops from neural stem cells (NSCs) and their differentiated neural cells; therefore,abnormal proliferation or differentiation of NSCs during early development may result in microcephaly [22]. Research using human NSCs in vitro and in vivo mouse models verifies that ZIKV infects NSCs and can cause dysregulated survival, cell death, and decreased neuronal differentiation [7,21,23-27]. Studiesusing an African lineage murine neuro-adapted ZIKV strain (MR766) demonstrated an efficient infection of ZIKV in neural progenitors that were induced from human skin fibroblasts, which resulted significant cell death and apoptosis [28,29].

These studies showed high rates of infectivity and cell death in their respective models. While these findings represent the pioneering work in vitro with ZIKV and stem cells, the viral strain utilized was not reflective of clinically circulating strains. MR766 is an African lineage strain of ZIKV and has been passaged in vitro numerous times [30]. As a result, there are some discrepancies between findings reported in studies using MR766 and clinical 
data. Specifically, clinical findings show only a small percentage of neural cells infected with ZIKV, and even though there is a reduction in neural populations, there is not a large amount of cell death $[13,16,31]$.

Another factor to note in studies using induced pluripotent stem cells is that these cells have been genetically manipulated and reprogrammed from mature cells into pluripotent cells. While it remains undetermined if this genetic manipulation may play a role in viral infectivity and subsequent cell behavior, it is important to note differences between these cells and primary fetal cells.

A study was recently conducted utilizing a ZIKV strain from an outbreak in Puerto Rico in 2015 (PRVABC59) to infect primary human fetal neural progenitors [32]. This study showed lower infectivity rates of ZIKV as well as lower levels of apoptosis compared to the studies using MR766. This study was more reflective of clinical findings, and demonstrated that different strains of ZIKV could yield variable results. To better understand why only a subset of infants develop microcephaly, we used an in vitro culture system ofprimary human fetal brain-derived NSCs from three individual donors [33], and evaluated the effects of a ZIKV strain isolated from a 2015 Mexican outbreak (Mex1-7) on NSC survival and differentiation. Mex1-7 decreased NSC proliferation in all three donor strains, and, similar to the study using PRVABC59, there was very little apoptosis [32]. Interestingly, Mex1-7, significantly reduced neurogenesis (a process generating neurons) in two of the three donor strains, whereas the third donor strain experienced no change in neurogenesis.

The two strains that had a reduction in neurogenesis came from donors that were 9- and 13-week old of gestation. The donor strain that experienced no reduction in neurogenesis was also 13-week old [33]. This is an important factor considering clinical reports indicate that the first trimester of pregnancy is the time when fetusesare most susceptible to detrimental effects of ZIKV infection [19]. The donor-dependent responses of human NSCs in this study raised interesting questions about individual vulnerability and resiliency factors. Specifically, our study showed that in the two susceptible donor strains, there were significant alterations in transcriptome, particularly with regards to innate immunity and neurogenesis [33]. This suggests that innate immunity may be a key regulator of ZIKV's neurological disruption.

Use of in vitro systems is a valuable asset for ZIKV studies. They provide a relatively easy and well controlled system for understanding mechanistic details of ZIKV infection and subsequent cellular pathologies [34-37]. Recently, in vitro studies have shown that previous exposure to Dengue virus may result in antibody-dependent enhancement of ZIKV symptoms [38-41]. Furthermore, they provide a platform for medium to high throughput screening of various drugs and therapeutics to combat ZIKV infection [42-49].

\section{In vivo studies regarding ZIKV contributions to microcephaly}

While in vitro systems are critically important for developing our understanding of key mechanistic details, in vivo studies are necessary for providing a more translational perspective regarding the development and systemic pathogenesis of ZIKV-associated microcephaly. In non-human primates, it has been shown that subcutaneous inoculation with ZIKV results in development of fetal brain lesions [50]. However, due to financial and ethical constraints of non-human primate studies, most work was conducted in rodent models.

It is known ZIKV directly infects NSCs of the fetus and impairs growth in mice $[18,20,51,52]$. Wu and colleagues showed that ZIKV can be vertically transmitted from mother to fetus and result in cortical development deficits [51]. This study was unique in that it used an Asian lineage ZIKV strain isolated from a patient during an acute phase of the infection, and was subsequently used to infect fetal mice. They found that ZIKV infection significantly reduced proliferative neural cortical progenitor cells and altered genes associated with microcephaly and cell cycle progression [51]. Another study conducted by Cugola used a Brazilian ZIKV strain to infect pregnant dams, and revealed that the pups displayed a variety of birth defects including brain malformations [53]. They also found that there was a significant upregulation in genes associated with autophagy and apoptosis, indicating that the developmentalabnormalities may be a result of dysregulated autophagy and increased cell death during development [53].

In 2016, Rossi and colleagues developed and characterized a novel murine model to study ZIKV infection [54]. This unique mouse model is deficient in interferon-alpha receptor and displays an age-dependent response to ZIKV infection. Additionally, this mouse model is shown to harbor virus in the testis, similar to humans, which may make this strain optimal in studying sexual transmission of ZIKV.The age-dependent response of this mouse may make it ideal for studying developmental deficits associated with ZIKV infection as well as screen various drugs at different stages of infection [54].

\section{Clinical studies regarding ZIKV contributions to microcephaly}

In addition to animal and cell culture models to elucidate the mechanism of ZIKV infection, clinical studies have made great strides in detection and characterization of ZIKV pathologies. A study by de Fatima Vasco Aragao and colleagues detailed computed tomography (CT) findings from 22 children with signs of ZIKV infection [55]. This study showed that $95 \%$ of children had cortical development malformations, and $91 \%$ had decreased brain volume [55]. Ventriculomegaly, or enlargement of the ventricles, was observed in all of the 8 children who also underwent MRI [55]. Another study by Strafela et al. reported similar findings from autopsy evaluation of a ZIKV-infected 
fetal brain approximately 33 weeks old [56]. Among signs of lissencephaly and pachgyria, ventriculomegaly and thinning of white matter was also present [56]. Despite the clear clinical signs associated with ZIKV infection during development, there reamin key barriers to early diagnosis. A recent manuscript by Kaushik and colleagues discusses the use of smart sensing techniques to monitor ZIKV infection progression during development [57]. Use of smart sensing techniques such as electrochemical biosensors increases availability and ease of efficient diagnosis, compared to the broadly used reverse transcription-polymerase chain reaction (TPCR) method of diagnosis [57].

\section{Conclusion}

Advances in cell culture and animal models are beginning to help us understand the mechanism of ZIKV-induced microcephaly, though much work is still needed [58]. It is apparent from current work that ZIKV causes decreased proliferation and neurogenic differentiation during fetal development.However, given the relatively low infectivity of circulating ZIKV strains, more work should be done to investigate how host determinants mediate the development of microcephaly.Future studies should begin to focus on individual vulnerability factors which may increase susceptibility to ZIKV-associated neurological deficits. In this regard, current literature suggests host immunity may be a promising target. Figure 1 outlines the current understanding of ZIKV infection progression and highlights the current areas being targeted to prevent ZIKV infection and associated neurological deficits (Figure 1). In conclusion,ZIKV continues to present a public health threat, and the associated risk of microcephaly warrants further investigation.

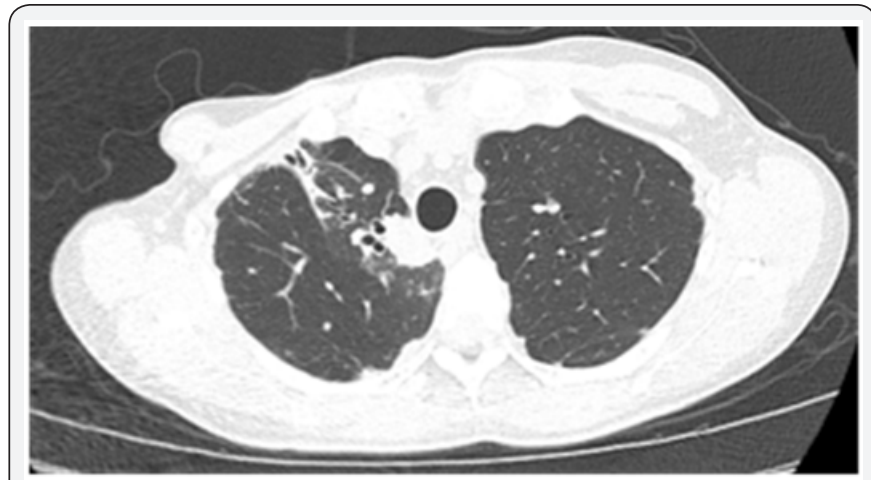

Figure 1: Showing a right paratracheal nodule measuring $23 \mathrm{x}$ $16 \mathrm{~mm}$ (arrow) done prior to treatment.

\section{Conflict of Interest}

The authors have no conflicts of interest to declare

\section{Acknowledgement}

E.L.M. drafted the manuscript and P.W. edited the manuscript. This work was supported by funds from the John S. Dunn Foundation (P.W.), R21AI129509- 01 (P.W. and N.V.),
4T32DA007287 (E.L.M.), and the Chief Research Office at the University of Texas Medical Branch (P.W.).

\section{References}

1. Kindhauser MK, Allen T, Frank V, Santhana RS, Dye C (2016) Zika: the origin and spread of a mosquito-borne virus. Bull World Health Organ 94(9): 675-686C.

2. Guerbois M, Fernandez-Salas I, Azar SR, Danis-Lozano R, AlpucheAranda CM, et al. (2016) Outbreak of Zika Virus Infection, Chiapas State, Mexico, 2015, and First Confirmed Transmission by Aedes aegypti Mosquitoes in the Americas. J Infect Dis 214(9): 1349-1356.

3. WHO. WHO's response to Zika virus and its associated complications. World Health Organization 2016.

4. Wang JN, Ling F (2016) Zika Virus Infection and Microcephaly: Evidence for a Causal Link. Int J Environ Res Public Health 13(10).

5. Haddow AD, Schuh AJ, Yasuda CY, Kasper MR, Heang V, et al. (2012) Genetic characterization of Zika virus strains: geographic expansion of the Asian lineage. PLoS Negl Trop Dis 6(2): e1477.

6. Weaver SC, Costa F, Garcia-Blanco MA, Ko AI, Ribeiro GS, et al. (2016) Zika virus: History, emergence, biology, and prospects for control. Antiviral Res 130: 69-80.

7. Broutet N, Krauer F, Riesen M, Khalakdina A, Almiron M, et al. (2016) Zika Virus as a Cause of Neurologic Disorders. N Engl J Med 374(16): 1506-1509.

8. Cao-Lormeau VM, Blake A, Mons S, Lastere S, Roche C, et al. (2016) Guillain-Barre Syndrome outbreak associated with Zika virus infection in French Polynesia: a case-control study. Lancet 387(10027): 15311539.

9. Paploski IA, Prates AP, Cardoso CW, Kikuti M, Silva MM, et al. (2016) Time Lags between Exanthematous Illness Attributed to Zika Virus, Guillain-Barre Syndrome, and Microcephaly, Salvador, Brazil. Emerg Infect Dis 22(8): 1438-1444.

10. Foy BD, Kobylinski KC, Chilson Foy JL, Blitvich BJ, Travassos da Rosa A, et al. (2011) Probable non-vector-borne transmission of Zika virus, Colorado, USA. Emerg Infect Dis 17(5): 880-882.

11. Hills SL, Russell K, Hennessey M, Williams C, Oster AM, et al. (2016) Transmission of Zika Virus Through Sexual Contact with Travelers to Areas of Ongoing Transmission - Continental United States, 2016. MMWR Morb Mortal Wkly Rep 65(8): 215-216.

12. Barjas-Castro ML, Angerami RN, Cunha MS, Suzuki A, Nogueira JS, et al. (2016) Probable transfusion-transmitted Zika virus in Brazil. Transfusion 56(7): 1684-1688.

13. Rasmussen SA, Jamieson DJ, Honein MA, Petersen LR. (2016) Zika Virus and Birth Defects--Reviewing the Evidence for Causality. N Engl J Med 374(20): 1981-1987.

14. Calvet G, Aguiar RS, Melo AS, Sampaio SA, de Filippis I, et al. (2016) Detection and sequencing of Zika virus from amniotic fluid of fetuses with microcephaly in Brazil: a case study. Lancet Infect Dis 16(6): 653660 .

15. Mlakar J, Korva M, Tul N, Popovic M, Poljsak-Prijatelj M, et al. (2016) Zika Virus Associated with Microcephaly. N Engl J Med 374(10): 951958.

16. Brasil P, Pereira JP, Moreira ME, Ribeiro Nogueira RM, Damasceno L, et al. (2016) Zika Virus Infection in Pregnant Women in Rio de Janeiro. N Engl J Med 375(24): 2321-2334.

17. Cauchemez S, Besnard M, Bompard P, Dub T, Guillemette-Artur P, et al. (2016) Association between Zika virus and microcephaly in French Polynesia, 2013-15: a retrospective study. Lancet 387(10033): 2125- 
2132.

18. Li C, Xu D, Ye Q Hong S, Jiang Y, et al. (2016) Zika Virus Disrupts Neural Progenitor Development and Leads to Microcephaly in Mice. Cell Stem Cell 19(1): 120-126.

19. Kleber de Oliveira W, Cortez-Escalante J, De Oliveira WT, do Carmo GM, Henriques CM, et al. (2015) Increase in Reported Prevalence of Microcephaly in Infants Born to Women Living in Areas with Confirmed Zika Virus Transmission During the First Trimester of Pregnancy Brazil, 2015. MMWR Morb Mortal Wkly Rep 65(9): 242-247.

20. Li H, Saucedo-Cuevas L, Regla-Nava JA, Chai G, Sheets N, et al. (2016) Zika Virus Infects Neural Progenitors in the Adult Mouse Brain and Alters Proliferation. Cell Stem Cell 19(5): 593-598.

21. Li H, Saucedo-Cuevas L, Shresta S, Gleeson JG (2016) The Neurobiology of Zika Virus. Neuronb 92(5): 949-958.

22. Honein MA, Dawson AL, Petersen EE, Jones AM, Lee EH, et al. (2017) Birth Defects Among Fetuses and Infants of US Women With Evidence of Possible Zika Virus Infection During Pregnancy. JAMA 317(1): 59-68.

23. Carod-Artal FJ (2016) Epidemiology and neurological complications of infection by the Zika virus: a new emerging neurotropic virus. Rev Neurol 62(7): 317-328.

24. Johansson MA, Mier-y-Teran-Romero L, Reefhuis J, Gilboa SM, Hills SL(2016) Zika and the Risk of Microcephaly. N Engl J Med 375(1): 1-4.

25. Miner JJ, Diamond MS (2016) Understanding How Zika Virus Enters and Infects Neural Target Cells. Cell Stem Cell 18(5): 559-560.

26. Pawitwar SS, Dhar S, Tiwari S, Ojha CR, Lapierre J, et al. (2017) Overview on the Current Status of Zika Virus Pathogenesis and Animal Related Research. J Neuroimmune Pharmacol.

27. Solomon IH, Milner DA, Folkerth RD (2016) Neuropathology of Zika Virus Infection. J Neuroinfect Dis 7(2): 200.

28. Qian X, Nguyen HN, Song MM, Hadiono C, Ogden SC, et al. (2016) BrainRegion-Specific Organoids Using Mini-bioreactors for Modeling ZIKV Exposure. Cell 165(5): 1238-1254.

29. Garcez PP, Loiola EC, Madeiro da Costa R, Higa LM, Trindade P, et al. (2016) Zika virus impairs growth in human neurospheres and brain organoids. Science 352(6287): 816-818.

30. Musso D, Gubler DJ. Zika Virus (2016) Clin Microbiol Rev 29(3): 487524.

31. Soares de Oliveira-Szejnfeld P, Levine D, Melo AS, Amorim MM, Batista AG, et al. (2016) Congenital Brain Abnormalities and Zika Virus: What the Radiologist Can Expect to See Prenatally and Postnatally. Radiology 281(1): 203-218.

32. Hanners NW, Eitson JL, Usui N, Richardson RB, Wexler EM, et al. (2016) Western Zika Virus in Human Fetal Neural Progenitors Persists Long Term with Partial Cytopathic and Limited Immunogenic Effects. Cell Rep 15(11): 2315-2322.

33. McGrath EL, Rossi SL, Gao J, Widen SG, Grant AC, et al. (2017) Differential Responses of Human Fetal Brain Neural Stem Cells to Zika Virus Infection. Stem Cell Reports 8(3): 715-727.

34. Zhang F, Hammack C, Ogden SC, Cheng Y, Lee EM, et al. (2016) Molecular signatures associated with ZIKV exposure in human cortical neural progenitors. Nucleic Acids Res 44(18): 8610-8620.

35. Zhang R, Miner JJ, Gorman MJ, Rausch K, Ramage H, et al. (2016) A CRISPR screen defines a signal peptide processing pathway required by flaviviruses. Nature 535(7610): 164-168.

36. Ghouzzi VE, Bianchi FT, Molineris I, Mounce BC, Berto GE, et al. (2016) ZIKA virus elicits P53 activation and genotoxic stress in human neural progenitors similar to mutations involved in severe forms of genetic microcephaly and p53. Cell Death Dis 7(10): e2440.
37. Grant A, Ponia SS, Tripathi S, Balasubramaniam V, Miorin L, et al. (2016) Zika Virus Targets Human STAT2 to Inhibit Type I Interferon Signaling. Cell Host Microbe 19(6): 882-890.

38. Bardina SV, Bunduc P, Tripathi S, Duehr J, Frere JJ, et al. (2017) Enhancement of Zika virus pathogenesis by preexisting antiflavivirus immunity. Science 356(6334): 175-180.

39. Dejnirattisai W, Supasa P, Wongwiwat W, Rouvinski A, Barba-Spaeth $\mathrm{G}$, et al. (2016) Dengue virus sero-cross-reactivity drives antibodydependent enhancement of infection with zika virus. Nat Immunol 17(9): 1102-1108.

40. Stettler K, Beltramello M, Espinosa DA, Graham V, Cassotta A, et al. (2016) Specificity, cross-reactivity, and function of antibodies elicited by Zika virus infection. Science 353(6301): 823-826.

41. Swanstrom JA, Plante JA, Plante KS, Young EF, McGowan E, et al. (2016) Dengue Virus Envelope Dimer Epitope Monoclonal Antibodies Isolated from Dengue Patients Are Protective against Zika Virus. Mbio 7(4)

42. Barrows NJ, Campos RK, Powell ST, Prasanth KR, Schott-Lerner G, et al. (2016) A Screen of FDA-Approved Drugs for Inhibitors of Zika Virus Infection. Cell Host Microbe 20(2): 259-270.

43. Xu M, Lee EM, Wen Z, Cheng Y, Huang WK, et al. (2016) Identification of small-molecule inhibitors of Zika virus infection and induced neural cell death via a drug repurposing screen. Nat Med 22(10):1101-1107.

44. Betancourt D, de Queiroz NM, Xia T, Ahn J, Barber GN (2017) Cutting Edge: Innate Immune Augmenting Vesicular Stomatitis Virus Expressing Zika Virus Proteins Confers Protective Immunity. J Immunol 198(8): 3023-3028.

45. Bullard-Feibelman KM, Govero J, Zhu Z, Salazar V, Veselinovic M, et al. (2017) The FDA-approved drug sofosbuvir inhibits Zika virus infection. Antiviral Res 137: 134-140.

46. Delvecchio R, Higa LM, Pezzuto P, Valadao AL, Garcez PP, et al. (2016) Chloroquine, an Endocytosis Blocking Agent, Inhibits Zika Virus Infection in Different Cell Models Viruses 8(12).

47. Quanquin N, Wang L, Cheng G (2017) Potential for treatment and a Zika virus vaccine. Curr Opin Pediatr 29(1): 114-121.

48. Julander JG, Siddharthan V, Evans J, Taylor R, Tolbert K, et al. (2017) Efficacy of the broad-spectrum antiviral compound BCX4430 against Zika virus in cell culture and in a mouse model. Antiviral Res 137: 1422.

49. Tan CW, Sam IC, Chong WL, Lee VS, Chan YF (2017) Polysulfonate suramin inhibits Zika virus infection. Antiviral Res 143: 186-194.

50. Adams Waldorf KM, Stencel-Baerenwald JE, Kapur RP, Studholme C, Boldenow E, et al. (2016) Fetal brain lesions after subcutaneous inoculation of Zika virus in a pregnant nonhuman primate. Nat Med 22(11): 1256-1259.

51. Wu KY, Zuo GL, Li XF, Ye Q, Deng YQ, et al. (2016) Vertical transmission of Zika virus targeting the radial glial cells affects cortex development of offspring mice. Cell Res 26(6): 645-654.

52. Brault JB, Khou C, Basset J, Coquand L, Fraisier V, et al. (2016) Comparative Analysis Between Flaviviruses Reveals Specific Neural Stem Cell Tropism for Zika Virus in the Mouse Developing Neocortex. EBioMedicine 10: 71-76.

53. Cugola FR, Fernandes IR, Russo FB, Freitas BC, Dias JL, (2016) et al. The Brazilian Zika virus strain causes birth defects in experimental models. Nature 534(7606): 267-271.

54. Rossi SL, Tesh RB, Azar SR, Muruato AE, Hanley KA, et al. (2016) Characterization of a Novel Murine Model to Study Zika Virus. Am J Trop Med Hyg 94(6): 1362-1369.

55. de Fatima Vasco Aragao M, van der Linden V, Brainer-Lima AM, Coeli RR, Rocha MA, et al. (2016) Clinical features and neuroimaging (CT and 
MRI) findings in presumed Zika virus related congenital infection and microcephaly: retrospective case series study. BMJ 13: 353.

56. Strafela P, Vizjak A, Mraz J, Mlakar J, Pizem J, et al. (2017) Zika virusassociated micrencephaly: A thorough description of neuropathologic findings in the fetal central nervous system. Arch Pathol Lab Med 141(1): 73-81.

57. Kaushik A, Tiwari S, Jayant RD, Vashist A, Nikkhah-Moshaie R, et al. (2017) Electrochemical biosensors for early stage zika diagnostics. Trends in Biotech 35(4): 308-317.
58. Pawitwar SS, Dhar S, Tiwari S, Ojha CR, Lapierre J, et al. (2017) Overview on the current status of zika virus pathogenesis and animal related research. J NeuroimmunePharmacol.

\section{Your next submission with Juniper Publishers will reach you the below assets}

- Quality Editorial service

- Swift Peer Review

- Reprints availability

- E-prints Service

- Manuscript Podcast for convenient understanding

- Global attainment for your research

- Manuscript accessibility in different formats ( Pdf, E-pub, Full Text, Audio)

- Unceasing customer service

Track the below URL for one-step submission https://juniperpublishers.com/online-submission.php 